\title{
BTEX IN AN OCCUPATIONAL ENVIRONMENT
}

\author{
EDUARDO MONTEIRO MARTINS ${ }^{1}$, PRISCILA FALCÃO DE SÁ BORBA ${ }^{1}$, NEEMIAS ESPINDOLA \\ DOS SANTOS ${ }^{1}$, PAULA THAISE BERMUDEZ DOS REIS ${ }^{1}$, RENATA SIMÕES SILVEIRA ${ }^{1}$, ISRAEL \\ FELZENSZWALB $^{1}$,ELISA RAQUEL ANASTÁCIO FERRAZ ${ }^{2}$, ANDREIA DA SILVA FERNANDES ${ }^{1}$, RONALD \\ DA SILVA MUNIZ², IZABELA BATISTA DE SOUZA MATOS ${ }^{2}$, SÉRGIO MACHADO CORREA ${ }^{1}$ \\ ${ }^{1}$ Rio de Janeiro State University, Brazil \\ ${ }^{2}$ Fluminense Federal University, Brazil
}

\begin{abstract}
The BTEX group (benzene, toluene, ethyl benzene and xylene) are known for their potential toxic, mutagenic and carcinogenic effects, especially in an indoor occupational environment, where these substances dissipate with greater difficulty. Thus, the present work evaluated the concentrations, mutagenicity and cytotoxicity of the BTEX group in the indoor air of workshops involving painting and varnishing. Samples were collected using air pumps from the outside of the open environment workshops and from the inside of each of the three workshops. The chemical analyses were carried out using gas chromatograph with mass spectrometry. The mutagenic and cytotoxicity potentials were determined using the Salmonella/microsome and WST/LDH assays, respectively. The concentrations of each constituent of the BTEX group were below the limits established by the National Institute for Occupational Safety and Health and toluene presented the highest value. Moreover, these compounds did not induce mutagenic activity in the TA98 and TA100 Salmonella typhimurium strains either in the presence or in the absence of metabolization, and no cytotoxic effects were observed in the A549 human lung cells. These results may be related to the low BTEX values found in the occupational environment, as can be seen in some other studies. Nevertheless, at low concentrations, these compounds may cause toxicity by a pathway not investigated in this study or may have interacted with other non-monitored air constituents, reducing their toxicity. The present study sought to obtain more information and clarifications regarding occupational exposure to BTEX, contributing to the risk assessment of the workers exposed to these substances.

Keywords: BTEX, exposure, indoor, mutagenicity, solvent, toxicity.
\end{abstract}

\section{INTRODUCTION}

Indoor air quality is an increasing concern, and the volatile organic compounds (VOCs) are the most important chemical compounds in indoor environments. VOCs are well known by the odor and toxic properties [1] and play a significant role in ozone formation in the troposphere and secondary aerosols. In indoor environments, VOCs have several emission sources such as paints, solvents, adhesives, furnishings, clothing, building materials and cleaning supplies. [2]-[5].

Among the different VOCs, commonly found VOCs in indoor environments are benzene, ethylbenzene, toluene and xylenes (BTEX), which have high potential damage to human health [6]. BTEX are well known to be toxic, mutagenic and/or carcinogenic [7], [8]. Benzene was associated with higher rates of leukemia and tumors in the occupational workers. Chronic exposures to toluene and xylenes have been associated with adverse effects on the nervous system, liver and kidney; chronic exposure to ethylbenzene has been related to adverse effects on the kidneys and respiratory system [9].

BTEX are commonly used by the chemical industry to prepare raw materials to manufacture pesticides, plastic, synthetic fibers, solvents, paints, foundries, electronics and pharmaceuticals [10]. These compounds tend to accumulate in the indoor occupational environment, exposing the workers to their risks [2], [11], [12]. Previous studies suggested that prolonged 
Table 1: Comparison of BTEX exposure limits in Brazil and USA.

\begin{tabular}{lcccc}
\hline \multirow{2}{*}{ Compounds } & NR-15 & ACGIH & NIOSH & OSHA \\
\cline { 2 - 5 } & \multicolumn{4}{c}{ ppm } \\
\hline Benzene & ND* & 10 & 0.1 & 1 \\
Toluene & 78 & 50 (skin) & 100 & 200 \\
Ethyl benzene & 78 & 100 & 100 & 100 \\
m+p-Xylenes & ${ }^{(2)} 78$ & 100 & 100 & 100 \\
o-Xylene & ${ }^{(2)} 78$ & 100 & 100 & 100 \\
\hline
\end{tabular}

ND - undefined. "Without safe limit.

exposure to chemical pollutants, such as BTEX, from different sources in occupational environments is one of the major factors in the deterioration of workers' health [13], [14].

Although there are previous reports on the toxicity of the BTEX constituents [15]-[17], there is little information about the toxicity of BTEX as a group.

The assessment of occupational exposure to chemicals, mainly BTEX, is performed based on the tolerance limits (TLs), which are regulated in Brazil by the Ministry of Work and Employment through the Regulatory Standard (NR-15) - Activities and Unhealthy Operations [18]. NR-15 lists the TLs, which were based on the publication of the American Conference of Governmental Industrial Hygienists (ACGIH) [19]. When an evaluated substance is not listed in NR-15, the NR-9 program for Environmental Risk Prevention [20] allows the adoption of occupational exposure limit values established by ACGIH.

A threshold limit value refers to the concentrations of a substance in the air and represents conditions under which it is believed that most workers can be exposed repeatedly, for a lifetime of work without adverse health effects [19].

Table 1 shows a comparison between the parameters of BTEX exposure limits in Brazil [19] and other international organizations, such as the National Institute for Occupational Safety and Health (NIOSH) [21] and the Occupational Safety and Health Administration (OSHA).

Several studies evaluated BTEX human exposure in occupational environments by combining the cancer risk calculations and adverse health effects [13], [14], [22]. The characterization of human exposure is a critical component of environmental and occupational epidemiological studies [23], and it is an essential step in regulatory processes [4].

This study monitored BTEX concentrations in a very common work environment in paint, carpentry and varnish workshops and evaluated the adverse health effects on workers from these environments due to the exposure to these compounds. BTEX were determined in indoor air of these environments and also in the raw materials used.

\section{MATERIALS AND METHODS}

\subsection{Study area}

The studied environments are carpentry, varnishing and painting workplaces and belong to the preventive maintenance, corrective and operational area from the Rio de Janeiro State University (UERJ). The building has 24 floors, and the study area is located on the ground floor. 
The workshops have poor natural ventilation through small windows to external area and artificial ventilation by fans. The rooms are equipped with wall hoods that promote a mechanical exhaust. The lighting is made artificially by fluorescent lamps. It is an area without public circulation and has only workers.

The exhaust equipment was frequently not working and incorrect procedures are adopted, for example, the use of uncapped products. Among the products used in the three workshops are alcohol, solvent, wax, water and oil-based paints, contact glue and turpentine. Table 2 summarizes the characteristics and activities performed in the workshops.

\subsection{Chemicals and cell culture}

The Ham's F12 medium was purchased from Thermo Fisher Scientific Inc. (Waltham MA, USA). Cell Proliferation Reagent WST-1 (Cat. No. 05015944 001) and Cytotoxicity detection kit (LDH, Cat. No. 11644793 001) were purchased from Roche, Mannheim, Germany. A549 lung carcinoma cell line was kindly provided by Dr. José Carlos Pelielo de Mattos (Department of Biophysics and Biometry, Roberto Alcantra Gomes Biology Institute, University of the State of Rio de Janeiro, Rio de Janeiro, RJ, Brazil). The S9 fractions were obtained from Moltox Inc., Boone, NC (USA), and were prepared from the livers of male Sprague-Dawley rats, pretreated with a polychlorinated biphenyl mixture (Aroclor 1254). HPLC-grade solvents were purchased from Merck (Darmstadt, Germany) and were filtered through nylon 0.45-mm-pore-size filters (Millipore Corp.). The mobile phases and all solutions were membrane filtered (nylon, $0.22-\mathrm{mm}$ pore size). Highly purified water with a resistivity of 18.1 MV-cm (Barnstead/Thermolyne, Dubuque, IA, USA) was used throughout the

Table 2: Physical characteristics and activities in the workshops.

\begin{tabular}{|c|c|c|c|}
\hline Workshop & Characteristics & Products & Activities \\
\hline Varnishing & $\begin{array}{l}\text { Total area: } 32 \mathrm{~m}^{2} \\
\text { Window area: } 3.44 \mathrm{~m}^{2} \\
\text { Height: } 3.50 \mathrm{~m}\end{array}$ & $\begin{array}{l}\text { Varnish, alcohol, } \\
\text { gasoline, turpentine, } \\
\text { solvent, beeswax, car- } \\
\text { nauba wax and paraffin }\end{array}$ & $\begin{array}{l}\text { Wood and furniture sur- } \\
\text { face finishing, such as } \\
\text { varnishing, lacquering, } \\
\text { waxing and coloring. }\end{array}$ \\
\hline Painting & $\begin{array}{l}\text { Total area: } 42 \mathrm{~m}^{2} \\
\text { Window area: } 4.60 \mathrm{~m}^{2} \\
\text { Height: } 3.50 \mathrm{~m}\end{array}$ & $\begin{array}{l}\text { Turpentine, solvent, } \\
\text { Poly(vinyl alcohol) } \\
\text { (PVA) paint, synthetic } \\
\text { paint, lacquer and } \\
\text { spackling }\end{array}$ & $\begin{array}{l}\text { Paint metal, wood, } \\
\text { plastic and other } \\
\text { materials, polish and } \\
\text { touch up painted sur- } \\
\text { faces and dry surfaces } \\
\text { and prepare painting } \\
\text { equipment. }\end{array}$ \\
\hline Carpentry & $\begin{array}{l}\text { Total area: } 175 \mathrm{~m}^{2} \\
\text { Window area: } 18 \mathrm{~m}^{2} \\
\text { Height: } 3.50 \mathrm{~m}\end{array}$ & $\begin{array}{l}\text { Contact glue, solid } \\
\text { wax, turpentine and } \\
\text { solvent }\end{array}$ & $\begin{array}{l}\text { Build, restore and } \\
\text { assemble wooden } \\
\text { structures, such as } \\
\text { wooden pieces, cabi- } \\
\text { nets, frames, packag- } \\
\text { ing, forms, slab liners } \\
\text { and dividers. }\end{array}$ \\
\hline
\end{tabular}


preparations and assays. The analytical-grade dimethyl sulfoxide (DMSO, CAS 67-68-5) was purchased from Merck (Darmstadt, Germany). High Concentration BTEX Mix, Bacto ${ }^{\mathrm{TM}}$ (CAS 9002-18-0), tryptone (CAS 91079-40-2), yeast extract (CAS 8013-01-2), biotin (CAS 58-85-5), histidine (CAS 71-00-1), sodium phosphate monobasic monohydrate (CAS 1004921-5), sodium phosphate dibasic (CAS 7558-79-4), 4-nitroquinoline-N-oxide (4-NQO, CAS 56-57-5), sodium azide (SA, CAS 26628-22-8), 2-aminoanthracene (2-AA, CAS 613-13-8), fetal bovine serum, trypsin-EDTA solution and penicillin-streptomycin were purchased from Sigma-Aldrich (St. Louis, Mo., USA). All chemicals and solvents were of analytical grade or the highest grade commercially available. Dichloromethane gas chromatography (GC) grade was purchased from Aldrich (414751), and methanol spectrophotometric grade was purchased from Sigma-Aldrich (154903). BTEX mix was a $2000 \mu \mathrm{g} \mathrm{mL} \mathrm{m}^{-1}$ certified reference material purchased from Supelco (CRM47993).

\subsection{Sampling}

Samples were collected from the outside of the open environment workshops from a distance of approximately $260 \mathrm{~m}$ and without the influence of the activities carried out in the workshops.

Twenty samples were collected inside each of the three workshops, and twenty samples were collected from the outdoor area. A total of 80 samples were collected between the months of December 2014 and February 2015, between 8 AM and 2 PM, which is a period of intensive work in these workshops.

Ten samples were collected from the main volatile products used in the workplaces to determine the BTEX concentrations by gas chromatography coupled to mass spectrometry (GC-MS). The solvents were conditioned in capped amber vials and stored under $-4^{\circ} \mathrm{C}$ prior to the analysis.

Samples were collected using four air pumps (KNF UNMP 850KNDC) operated at 700 $\mathrm{mL} \mathrm{min}^{-1}$ for a period of $3 \mathrm{~h}$ using double bed $(100 / 50 \mathrm{mg}$ ) coconut shell cartridges (SKC 226-01) according to the methodologies described in several works [12], [24]-[30].

\subsection{Chemical analyses}

Samples were extracted with $1,000 \mu \mathrm{L}$ of dichloromethane at $-20^{\circ} \mathrm{C}$ for $10 \mathrm{~min}$ in an ultrasonic bath [28], [30]. Chemical analyses were performed using a Varian 450GC coupled to a Varian MS220 mass spectrometer with an HP 5 MS capillary column (30 m, $0.32 \mathrm{~mm}, 0.25$ $\mu \mathrm{m})$ using Helium at $1.2 \mathrm{~mL} \mathrm{~min}^{-1}$. Sample extracts were analyzed using a $1.0 \mu \mathrm{L}$ splitless injection at $200^{\circ} \mathrm{C}$. The column temperature began at $40^{\circ} \mathrm{C}$ for $4 \mathrm{~min}$, and it was heated at

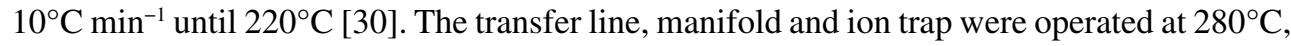
$50^{\circ} \mathrm{C}$ and $250^{\circ} \mathrm{C}$, respectively, using $50 \mu \mathrm{A}$. Selective ion monitoring operated using 78,91 and $109 \mathrm{~m} / \mathrm{z}$ as principal ions.

The analytical curves were performed in triplicate injections ranging from 100 to 20,000 $\mu \mathrm{g} \mathrm{L}^{-1}$, as well as a solvent blank. The detection and quantification limits for all BTEX samples were 12 and $35 \mu \mathrm{g} \mathrm{L}{ }^{-1}$, respectively. The determination coefficients for all BTEX samples were greater than 0.99 .

The samples were extracted as reported before [31] with some modifications. On the day of exposure, the active carbon beads of each cartridge containing BTEX, in hermetically sealed vials, were placed in contact with $1 \mathrm{~mL}$ of DMSO for $30 \mathrm{~min}$ in an ultrasonic bath. A pool of all the samples obtained from each workshop was then prepared and the experiments carried out. 


\subsection{Risks to human health}

The workers' health risks from exposure to BTEX in the areas studied were assessed [32]. Equation (1) was used to calculate the risk, as suggested by the Risk Assessment Guidance for Superfund developed by the U.S. EPA [33].

$$
\mathrm{EC}=\frac{\mathrm{CA} \cdot \mathrm{ET} \cdot \mathrm{FE} \cdot \mathrm{ED}}{\mathrm{AT}},
$$

where EC is the exposure concentration $\left(\mu \mathrm{g} \cdot \mathrm{m}^{-3}\right), \mathrm{CA}$ is the contaminant concentration in the air $\left(\mu \mathrm{g} \cdot \mathrm{m}^{-3}\right)$, ET is the exposure time $\left(\mathrm{h} \mathrm{day}{ }^{-1}\right)$, FE is the frequency of exposure (day year ${ }^{-1}$ ), ED is the exposure duration (years) and AT is the average time (lifetime in years $\times 365$ days year $\left.{ }^{-1} \times 24 \mathrm{~h} \mathrm{day}^{-1}\right)$.

Using eq (2) and the EC value calculated for each pollutant, the danger coefficient (HQ) was estimated and was compared to the inhalation reference concentration (RFC) with EC [33]:

$$
\mathrm{HQ}=\frac{\mathrm{EC}}{\text { Toxicity value } \times 1,000 \mu \mathrm{g} \mathrm{mg}^{-1}}
$$

where HQ is the danger coefficient, EC is the exposure concentration $\left(\mu \mathrm{g} \cdot \mathrm{m}^{-3}\right)$ and Toxicity value $\left(\mathrm{mg}^{-3}\right)$ is the inhalation RFC. By calculation, it is possible to estimate the probability of not contracting cancer, using eq (3).

$$
\mathrm{CR}=\mathrm{IRU} . \mathrm{EC}
$$

where $\mathrm{CR}$ is the carcinogenic risk and IRU is the inhalation risk unit

\subsection{Salmonella/microsome assay}

The preincubation protocol in the absence and presence of exogenous metabolism (S9, 4\% w/v mix) was carried out using the screening TA98 (hisD3052, rfa, $\Delta$ bio, $\Delta$ uvrB and pKM101) and TA100 (hisG46, rfa, $\Delta$ bio, $\Delta$ uvrB and pKM101) Salmonella typhimurium strains have been shown to identify approximately $90 \%$ of the mutagens in a population containing about $35 \%$ mutagenic chemicals [22]. Briefly, $100 \mu \mathrm{L}$ aliquots of each Salmonella culture $\left(10^{9}\right.$ cells $\left./ \mathrm{mL}\right), 100 \mu \mathrm{L}$ of different concentrations of the BTEX extract diluted in DMSO $(6.25 \%, 12.5 \%, 25 \%, 50 \%$ and $100 \%)$ and $500 \mu \mathrm{L}$ of $0.2 \mathrm{M}$ phosphate buffer $(\mathrm{pH}$ 7.4) were mixed for the assay in the absence of metabolic activation, or the same volume of the S9 mixture for the assay in the presence of metabolic activation, and incubated at $37^{\circ} \mathrm{C}$ for $20 \mathrm{~min}$ with shaking $(150 \mathrm{rpm})$. An aliquot of $2.0 \mathrm{~mL}$ molten top agar supplemented with biotin and a trace of histidine was then added to each tube, and the mixture homogenized and poured into a petri dish containing $20 \mathrm{~mL}$ of minimal agar. The plates were incubated for $72 \mathrm{~h}$ at $37^{\circ} \mathrm{C}( \pm 0.5)$, and the test was carried out in triplicate. DMSO was used as the negative control, and the positive controls in the absence of S9 were $0.5 \mu \mathrm{g} /$ plate of 4NQO for TA98 and $5 \mu \mathrm{g} /$ plate of SA for TA100. For the two strains, in the presence of S9, the positive control was 2 -AA $(2.5 \mu \mathrm{g} / \mathrm{plate})$. The toxicity was evaluated from the background growth.

All strains used in the present work are from our laboratory collection. 


\subsection{Cytotoxicity assay}

The A549 lung carcinoma cell line was cultured in Ham's F12 medium containing 10\% heatinactivated fetal bovine serum and $1 \%$ penicillin/streptomycin $\left(10,000 \mathrm{U}: 10 \mathrm{mg} \mathrm{mL} \mathrm{m}^{-1}\right)$ at $37^{\circ} \mathrm{C}$ with $5 \% \mathrm{CO}_{2}$. The BTEX pool extracted with DMSO and collected from the painting and vanishing workshops was diluted in F12 medium such that less than $0.1 \%$ of DMSO remained in the culture medium. Thus, $4 \times 10^{4} \mathrm{~A} 549$ cells grown in monolayers were seeded into each well of a sterile flat-bottomed 96-well plate and incubated with $6.25 \%, 12.5 \%$, $25 \%, 50 \%$ and $100 \%$ of the BTEX pool for 24,48 and $72 \mathrm{~h}$. The negative control was $0.1 \%$ DMSO and 2\% Triton-X100 was the positive control.

\subsection{WST-1 assay}

The WST-1 assay uses the highly water-soluble tetrazolium salt (4- [3- (4-iodophenyl) -2(4-nitrophenyl) -2H-5-tetrazolium] -1,3-benzene disulfonate) to determine the number of viable cells after exposure to BTEX. This salt is reduced by the mitochondrial dehydrogenases of the live cells giving a yellow product, which is soluble in the medium used in the cell culture. Briefly, after the treatments, $10 \mu \mathrm{L}$ of the WST- 1 reagent was added to $90 \mu \mathrm{L}$ of the cell cultures, which were maintained at $37^{\circ} \mathrm{C}$ and $5 \% \mathrm{CO}_{2}$ for $3 \mathrm{~h}$, and the absorbance measured at $450 \mathrm{~nm}$ using a Polaris Microplate Reader (Celer, Brazil) according to the manufacturer's recommendations. The higher the absorbance, the greater is the activity of the mitochondrial dehydrogenases and the greater is the viability of the cells. The results were expressed as the percentage of the negative control, which was designated as having $100 \%$ viability.

\subsection{LDH assay}

After treatment with BTEX, the cell membrane integrity was assessed from the release of intracellular lactate dehydrogenase (LDH), as LDH oxidizes the buffered l-lactate substrate at $\mathrm{pH} 9.4$ in the presence of $\mathrm{NAD}^{+}$generating pyruvate and $\mathrm{NADH}, \mathrm{H}^{+}$. The catalyst (diaphorase) then transfers $\mathrm{H} / \mathrm{H}^{+}$from $\mathrm{NADH}^{+} \mathrm{H}^{+}$to the tetrazolium salt INT, which absorbs light at $492 \mathrm{~nm}$. Briefly, after the treatments, $100 \mu \mathrm{L}$ of the culture medium was transferred to each well of a 96-well plate, and $100 \mu \mathrm{L}$ of the kit reagent solution added. The plates were incubated for $30 \mathrm{~min}$ at $20^{\circ} \mathrm{C}$ in the light, and the reading was made at $492 \mathrm{~nm}$ using a Polaris Microplate Reader (Celer, Brazil). The higher the absorbance, the greater is the release of $\mathrm{LDH}$ and the greater is the cytotoxicity. The results were expressed as percentage of lactate release of the positive control, which was designated as $100 \%$ of lactate release.

\subsection{Statistical analysis}

The results were statistically evaluated using the analysis of variance (ANOVA) and Dunnett's post hoc test, and the samples were considered positive when $p<0.05$. A multivariate correlation was carried out using R Language [34]. All assays were performed in triplicate at least two times. 


\section{RESULTS AND DISCUSSION}

\subsection{Results for BTEX}

Figure 1 shows the results for the BTEX in the three workplaces evaluated. The highest concentrations for benzene and toluene were observed in paint workshop were 3.6 and 788.3 $\mu \mathrm{g} \cdot \mathrm{m}^{3}$, respectively. For ethyl benzene, $\mathrm{m}+\mathrm{p}$-xylenes, the highest concentrations found in the varnish workshop were $284.0,484.6$ and $265.9 \mu \mathrm{g} \mathrm{m}^{-3}$. The high standard deviations are explained by the different activities undertaken, the several emission sources and the manner that each worker used the products. The high number of samples is considered to be representative for evaluating the workers' exposure. The lower standard deviation was found for benzene in the three workshops, indicating that the solvents used are not significant sources of benzene. For outdoor samples, the standard deviation obtained for each of BTEX samples indicates that there is a single source, which is likely vehicular emission from tailpipe and evaporative emissions because the testing site is a large parking lot.

In the three workshops evaluated, toluene was the most abundant compound, representing $43 \%, 49 \%$ and $69 \%$ for varnish, paint and carpentry workshops, respectively. In the external environment, ethyl benzene and toluene were the most representative BTEX values, with $32 \%$ of each.

Benzene concentrations were close to those found in different studies [30], [35], except for samples collected in landfill areas [1], [36]. The highest BTEX concentrations at the landfill area exceeded the maximum value obtained in the three workshops.
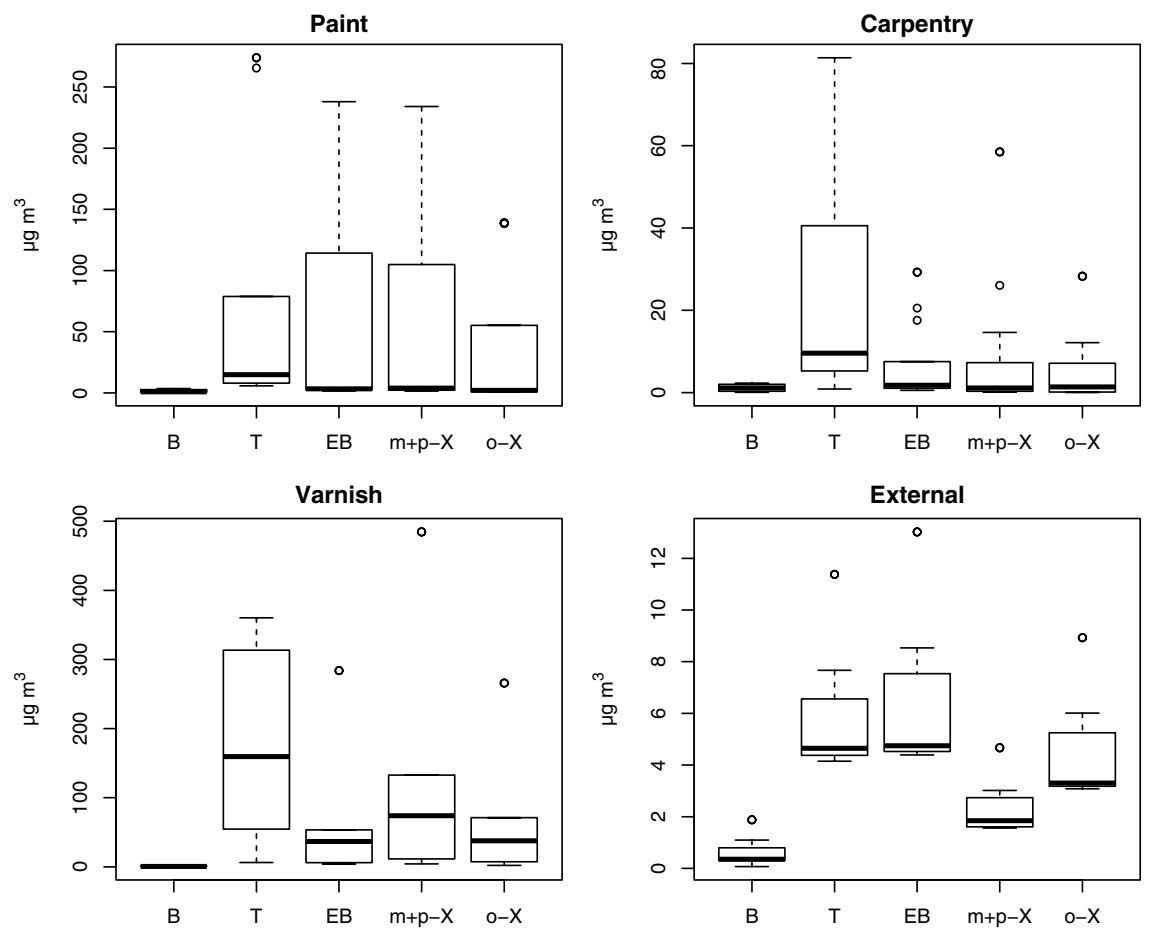

Figure 1: Summary of BTEX concentrations. 
The correlation between BTEX values showed characteristic profiles. Benzene only had high correlation $(>0.70)$ in the paint workshop, with correlations of 0.86 and 0.87 with $\mathrm{m}+\mathrm{p}$ xylenes and o-xylene, respectively. The benzene-toluene correlation was low in all sites. Compounds that showed correlations greater than 0.85 were ethylbenzene and xylenes in all three workshops, indicating that each sample came from the same source. Toluene only showed a high relationship with ethylbenzene and xylenes in the carpentry workshop; this relationship was possibly due to the use of contact adhesive, which is the only product that is exclusively used in carpentry.

Table 3 shows the ratio of BTEX concentrations obtained in the indoor and outdoor environments. For benzene, the higher ratio was obtained in the paint workshop. The highest BTEX ratios were found at varnish and paint workshops, where all BTEX concentrations were also higher. The high values for the indoor/outdoor ratio indicate the existence of significant internal sources of these compounds.

According to Guo et al. [4], the ratio value between the indoor (I) and outdoor sources (O) is a determining factor for the identification of BTEX sources, and it is a better parameter than absolute concentrations. If I/O > 1, there must be indoor sources of pollution [37], [38], and a detailed investigation must be done to prevent workers' exposure.

In comparison to the study by Guo et al. [4], which was performed in different environments such as offices, homes, schools, shopping malls and restaurants in Hong Kong, i.e., places where the vehicular air pollution was a significant source of VOCs, the values found in this study were higher, probably due to the use of organic solvents in the workshops emitting BTEX.

The values of I/O obtained by Vilavert et al. [32] were higher than 400, establishing a positive correlation for indoor-outdoor BTEX concentrations, making the existence of significant occupational exposure levels within the installation evident.

In the study by Jung et al. [39] that was conducted in the neighborhood of an airport, BTEX I/O ratios above 1 were found, which were mainly for toluene due to chemical products used for cleaning. According to Jung et al. [39], the ratio of benzene and toluene has been widely used as an emission source indicator. The presence of benzene is assigned to vehicular emissions, while the presence of toluene is also allocated to vehicular emissions from tailpipe and evaporative emissions. Generally, several authors that highlight the origin of these compounds in the atmosphere use the toluene and benzene (T/B) ratios. Values of T/B above 4 indicate predominant sources of evaporative emissions and similar solvents [40], [41]. The T/B values were $81.73,41.42$ and 190.49 for paint, carpentry and varnish workshops, respectively, indicating that there was a significant contribution by the products used.

Table 3: I/O BTEX ratios for the workshops.

\begin{tabular}{lccccc}
\hline \multicolumn{5}{c}{ Indoor/outdoor ratio } \\
\hline Workshops & Benzene & Toluene & Ethyl benzene & m+p-Xylenes & o-Xylene \\
\hline Paint & 2.6 & 20.6 & 7.0 & 22.6 & 6.8 \\
Carpentry & 1.9 & 7.7 & 1.0 & 3.6 & 1.1 \\
Varnishing & 1.6 & 29.5 & 9.4 & 48.6 & 13.6 \\
\hline
\end{tabular}


3.2 Chemical analysis of the products used in the workplaces

Table 4 presents the concentrations found for the raw materials used in each workshop, and Table 5 shows the chemical composition of the raw material used. Samples 1 to 4 presented higher BTEX concentrations, and these raw materials are the most commonly used in the paint and varnishing workshops. This finding is indicative of a positive correlation with the results found previously. Benzene was not found in the raw material, indicating that the I/O ratios are correct.

\subsection{Human health risks}

The carcinogenic and non-carcinogenic risks due to continuous BTEX exposure were assessed from the benzene results for each of workplace. Table 6 presents the average, maximum and

Table 4: BTEX values found in the raw materials used in the workplaces.

\section{Sample Raw materials}

\begin{tabular}{|c|c|c|c|c|c|}
\hline 1 & Surface & 0.552 & 0.173 & 0.416 & 0.340 \\
\hline 2 & Paint and solvent & 0.324 & 0.092 & 0.246 & 0.217 \\
\hline 3 & Nitrocellulose paint & 1.080 & 0.479 & 0.976 & 0.911 \\
\hline 4 & Solvent & 3.909 & 2.883 & 1.922 & 4.071 \\
\hline 5 & Acrylic water-based paint & 0.003 & 0.003 & 0.007 & 0.005 \\
\hline 6 & PVA water-based paint & 0.001 & 0.001 & 0.004 & 0.003 \\
\hline 7 & Synthetic paint & 0.012 & 0.067 & 0.148 & 0.124 \\
\hline 8 & Maritime varnish & 0.002 & 0.018 & 0.043 & 0.037 \\
\hline
\end{tabular}

Table 5: Chemical composition of the raw materials.

\begin{tabular}{ll}
\hline Raw materials & Chemical composition \\
\hline Surface & $\begin{array}{l}\text { Epoxy resin and aliphatic polyamines. } \\
\text { Alkyd resins and nitrocellulose. }\end{array}$ \\
Acrylic water-based paint & $\begin{array}{l}\text { Alkyd resin, organic and inorganic pigments, dryers, addi- } \\
\text { tives and aliphatic solvent with a small part of aromatics. }\end{array}$ \\
PVA paint & $\begin{array}{l}\text { Water solution, acrylic resin, vinyl ether, charges, cellu- } \\
\text { lose ester, polyether, oil, organic solvents and pigment. }\end{array}$ \\
Solvent & $\begin{array}{l}\text { Aromatic hydrocarbons, glycol ethers, alcohols and } \\
\text { ketones. }\end{array}$ \\
Synthetic paint & $\begin{array}{l}\text { Alkyd resin, inorganic and organic pigments, dryer, addi- } \\
\text { tives and aliphatic solvent with a small part of aromatics. } \\
\text { Mixture of solvent and paints. }\end{array}$ \\
Paint with solvent & Resin, pigments, additives and solvent. \\
Maritime varnish &
\end{tabular}


minimum risks for the three studied workshop types. The carcinogenic risk for the varnish workshop was $2.58 \times 10^{-7}$. This value was lower than that found by Vilavert et al. [32], who studied locations near an organic waste treatment plant, as well as the value found by Dutta et al. [42] in a bus station near roads and houses; however, the value was higher than the carcinogenic risk calculated in a landfill by Palmiotto et al. [43].

For the varnish workshops, the higher non-carcinogenic risks for the $\mathrm{m}+\mathrm{p}$-xylenes and $\mathrm{o}-\mathrm{xylene}$ were 0.088 and 0.048 , respectively. Toluene is the most abundant BTEX in the three evaluated workshops, and it had the highest non-carcinogenic risk in the paint workshop.

According to LaGrega et al. [44], the carcinogenic risk can be considered indifferent when it is less than $1.00 \times 10^{-6}$, but it is considered significant when it is greater than $1.00 \times 10^{-3}$ [45]; the non-carcinogenic risk can be considered indifferent when it is equal to 1.0 [44].

When comparing non-carcinogenic risk values, it can be observed that values were below 1.0 in all workshops, indicating that there was no non-carcinogenic risk. In the case of carcinogenic risk, the mean values ranged from $9.19 \times 10^{-7}$ to $5.7 \times 10^{-7}$, and the carcinogenic potential also was considered indifferent. Maximum values were just above $1.00 \times 10^{-6}$ and may be considered more expressive. Table 6 shows the carcinogenic and non-carcinogenic risks of BTEX exposure in the workshops.

The approach used here was possible only due to the data set obtained in these workplaces. A more robust methodology is detailed in the works of Sarigiannis et al. [46], [47] and Karakitsios et al. [48]. They developed a methodology for assessment of the determinants that comprise the overall leukemia risk due to benzene exposure and how these are affected by the other pollutants. An integrated modeling environment was constructed with several variables,

Table 6: Carcinogenic and non-carcinogenic risks to BTEX exposure for the workplaces.

\begin{tabular}{|c|c|c|c|c|c|c|}
\hline \multirow{3}{*}{ BTEX } & \multicolumn{6}{|c|}{ Paint } \\
\hline & \multicolumn{3}{|c|}{ Non-carcinogenic risk } & \multicolumn{3}{|c|}{ Carcinogenic risk } \\
\hline & Average & Maximum & Minimum & Average & Maximum & Minimum \\
\hline Benzene & $3.93 \times 10^{-3}$ & $1.01 \times 10^{-2}$ & $1.02 \times 10^{-3}$ & $9.19 \times 10^{-7}$ & $2.37 \times 10^{-6}$ & $2.38 \times 10^{-7}$ \\
\hline Toluene & $1.93 \times 10^{-3}$ & $1.35 \times 10^{-2}$ & $9.88 \times 10^{-5}$ & - & - & - \\
\hline Ethyl benzene & $3.53 \times 10^{-3}$ & $2.04 \times 10^{-2}$ & $1.20 \times 10^{-4}$ & - & - & - \\
\hline $\mathrm{m}+\mathrm{p}$-Xylenes & $4.12 \times 10^{-2}$ & $2.00 \times 10^{-1}$ & $1.25 \times 10^{-3}$ & - & - & - \\
\hline o-Xylene & $2.41 \times 10^{-2}$ & $1.19 \times 10^{-1}$ & $5.43 \times 10^{-4}$ & - & - & - \\
\hline \multicolumn{7}{|c|}{ Carpentry } \\
\hline Benzene & $2.91 \times 10^{-3}$ & $6.49 \times 10^{-3}$ & $1.97 \times 10^{-4}$ & $6.80 \times 10^{-7}$ & $1.52 \times 10^{-6}$ & $4.62 \times 10^{-8}$ \\
\hline Toluene & $7.23 \times 10^{-4}$ & $6.96 \times 10^{-3}$ & $1.50 \times 10^{-5}$ & - & - & - \\
\hline Ethyl benzene & $5.07 \times 10^{-4}$ & $2.51 \times 10^{-3}$ & $4.68 \times 10^{-5}$ & - & - & - \\
\hline $\mathrm{m}+\mathrm{p}$-Xylenes & $6.63 \times 10^{-3}$ & $5.01 \times 10^{-2}$ & $8.97 \times 10^{-5}$ & - & - & - \\
\hline o-Xylene & $3.87 \times 10^{-3}$ & $2.42 \times 10^{-2}$ & $2.45 \times 10^{-5}$ & - & - & - \\
\hline \multicolumn{7}{|c|}{ Varnish } \\
\hline Benzene & $2.44 \times 10^{-3}$ & $4.64 \times 10^{-3}$ & $1.10 \times 10^{-3}$ & $5.7 \times 10^{-7}$ & $1.09 \times 10^{-6}$ & $2.58 \times 10^{-7}$ \\
\hline Toluene & $2.77 \times 10^{-3}$ & $6.17 \times 10^{-3}$ & $1.05 \times 10^{-4}$ & - & - & - \\
\hline Ethyl benzene & $4.79 \times 10^{-3}$ & $2.43 \times 10^{-2}$ & $3.34 \times 10^{-4}$ & - & - & - \\
\hline $\mathrm{m}+\mathrm{p}$-Xylenes & $8.84 \times 10^{-2}$ & $4.15 \times 10^{-1}$ & $3.57 \times 10^{-3}$ & - & - & - \\
\hline o-Xylene & $4.82 \times 10^{-2}$ & $2.28 \times 10^{-1}$ & $1.71 \times 10^{-3}$ & - & - & - \\
\hline
\end{tabular}


such as traffic emissions, dispersion models, human exposure models and a coupled internal dose/biology-based dose-response risk assessment model, in order to assess the benzeneimposed leukemia risk, as much as the impact of traffic fleet renewal and smoking banning to these levels. This may result in lower or greater toxicity of mixtures than what would be expected by summing the toxicity of individual chemicals.

\subsection{Salmonella/microsome assay}

Figures 2 and 3 show the results obtained from the mutagenicity assessment of the air collected from the varnishing and painting workshops. The results are judged to be positive

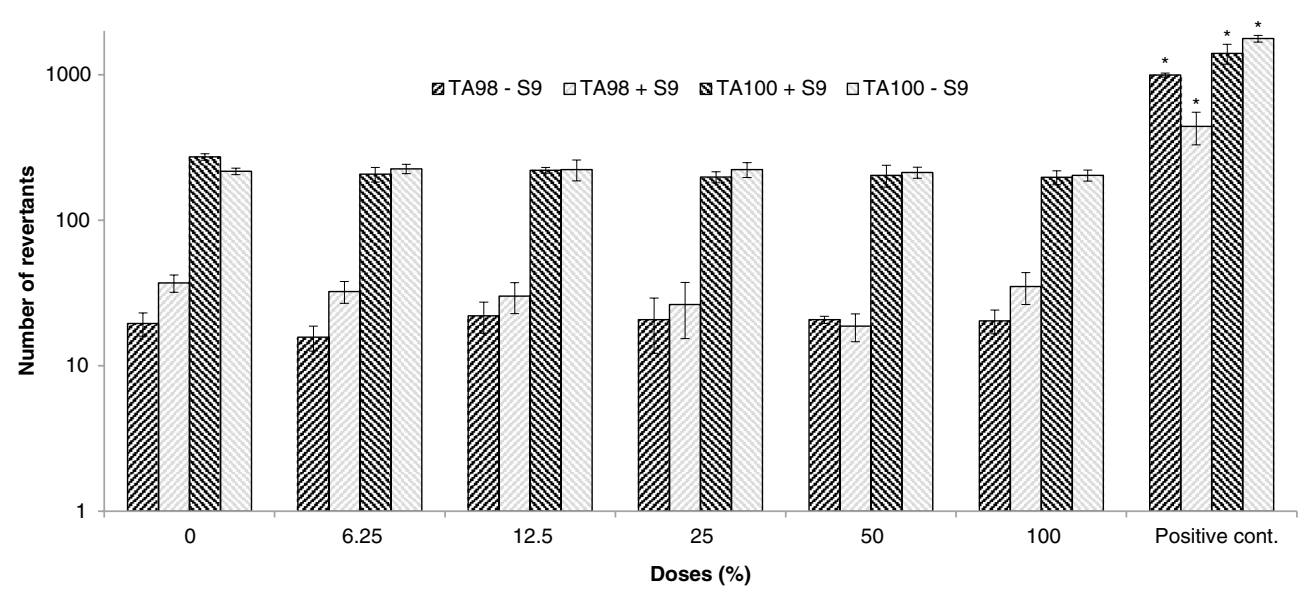

Figure 2: Response curve for BTEX (benzene, toluene, ethyl benzene and xylene) collected from the varnishing workplace when tested with the Salmonella strains TA98 and TA100 in the presence and absence of exogenous metabolic activation (S9), ${ }^{*} p<0.05$. Data are representative of three independent experiments.

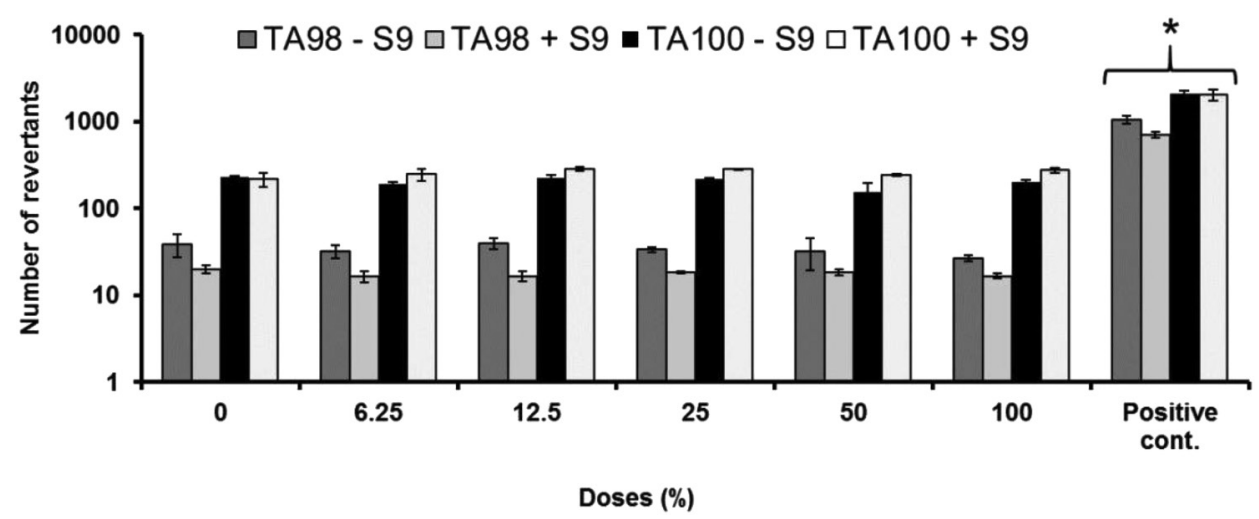

Figure 3: Response curve for BTEX (benzene, toluene, ethyl benzene and xylene) collected from the painting workplace when tested with the Salmonella strains TA98 and TA100 in the presence and absence of exogenous metabolic activation (S9). ${ }^{*} p<0.05$. Data are representative of three independent experiments. 
when the number of revertant colonies in each treated group increases with increase in the sample concentration, reaching at least twice the number in the negative control group. It can be seen that the samples did not show mutagenic activity in the TA98 and TA100 Salmonella strains under any of the conditions evaluated.

\subsection{Cytotoxicity assays}

Figures 4 and 5 show the results of the cytotoxicity evaluation of the air collected in the varnishing and painting workshops, respectively, after 24,48 and $72 \mathrm{~h}$ of exposure. The BTEX samples did not induce cytotoxicity in the A549 cell line, neither by disrupting the dehydrogenase activity (WST-1 assay) nor by disrupting the cell membrane (LDH assay).

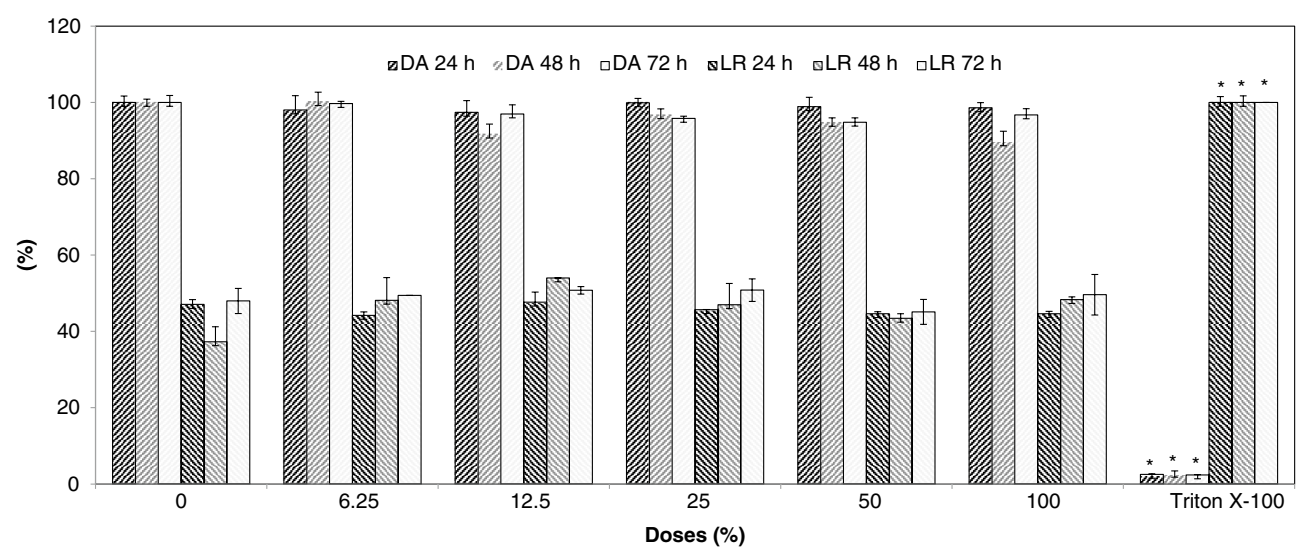

Figure 4: Effect of the BTEX (benzene, toluene, ethylbenzene and xylene) collected from the varnishing workplace on the dehydrogenase activity (DA) and lactate release (LR) of the A549 cell line after 24,48 and $72 \mathrm{~h}$ of exposure. The asterisks indicate significant differences at $p<0.05$. Data are representative of three independent experiments.

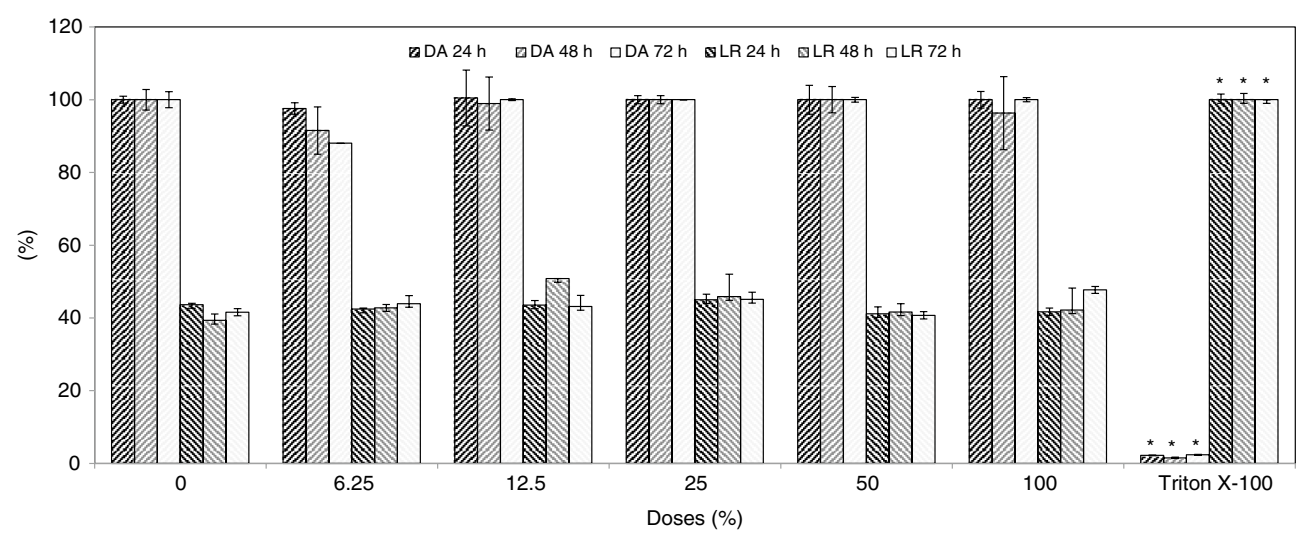

Figure 5: Effect of the BTEX (benzene, toluene, ethylbenzene and xylene) collected from the painting workplace on the dehydrogenase activity (DA) and lactate release (LR) of the A549 cell line after 24,48 and $72 \mathrm{~h}$ of exposure. The asterisks indicate significant differences at $p<0.05$. Data are representative of three independent experiments. 
The largest sources of BTEX found in indoor areas are from the evaporation of gasoline and vehicle emissions [49]. Based on indoor BTEX concentrations, the highest value was obtained for toluene since this compound is the main aromatic hydrocarbon present in many solvents and in gasoline, but this value is lower than the time-weighted average (TWA) value of the NIOSH value limit $\left(377 \mathrm{mg} \cdot \mathrm{m}^{-3}\right)$. The values found for benzene were much lower than the NIOSH value limit $\left(319 \mu \mathrm{g} \cdot \mathrm{m}^{-3}\right)$, but according to the Brazilian exposure limit (NR-15), there is no safe exposure level for benzene and the value should be zero. For the other aromatics evaluated, the values were also lower than the NIOSH limits $\left(434 \mu \mathrm{g} \cdot \mathrm{m}^{-3}\right)$. Even when below the limits recommended by the NIOSH, it is important to emphasize that the workers are exposed to the BTEX vapors for long period of time during the working day, and thus, the risk assessment is very important for the health of these workers.

Moreover, the BTEX concentrations found in the workshops studied were significantly higher than in the outdoor area, showing that the workers were occupationally exposed to high levels of BTEX when compared to the general population. For this reason, this study evaluated the mutagenic and cytotoxicity effects of the workshop air samples in order to estimate the risk to the workers.

Based on the Salmonella mutagenicity assay, the indoor air of the workshops did not present mutagenic potential for the TA98 and TA100 Salmonella strains, which shows that these samples did not induce base-pair substitution, frameshift or transition/transversion mutations [50]. The same was observed in cytotoxicity using the A549 human lung cell line.

The BTEX samples collected in the painting and varnishing workshops did not induce cytotoxicity in these cells after 24,48 and $72 \mathrm{~h}$ of exposure, neither by disrupting the dehydrogenase activity (WST-1 assay) nor by disrupting the cell membrane (LDH assay). These results may be related to the low BTEX concentrations found in the workshops. In a study carried out before [51], it was found that BTEX only increased the frequency of micronucleated rat hepatoma tissue culture cells at the highest concentration tested $(902.34,168.70,40.40$ and $11.74 \mathrm{mg} \mathrm{L}^{-1}$ for benzene, toluene, ethyl benzene and xylenes, respectively), values much higher than those found in the air of the workshops evaluated in this study.

Using [1] mathematical calculations to carry out heath risk assessments for workers exposed to BTEX via inhalation at a landfill, it was considered the effects of the individual BTEX compounds according to their carcinogenicities and found that the mean cancer risk for benzene was estimated as lower than the designated acceptable risk, while the mean noncarcinogenic risks for toluene, ethyl benzene and xylene, both individually and cumulatively, were lower than the specified level of 1.0. It was concluded that the landfill BTEX emissions did not pose a health threat to the workers at the landfill site. It is important to point out that the concentrations found were 140.3, 1271.7, 239.9 and $341.3 \mu \mathrm{g} \mathrm{m} \mathrm{m}^{-3}$ for benzene, toluene, ethyl benzene and xylenes, respectively, values much higher than those found in the present study. With respect to benzene, the only compound within the BTEX group proven to be carcinogenic to humans according to the International Agency for Research on Cancer (IARC) [52], in vitro tests have shown this compound has low or even no mutagenic action, although it has been shown to cause many types of genetic damage, such as clastogenic and aneugenic effects, inducing micronuclei, chromosomal aberrations, sister chromatid exchanges and DNA strand breaks. Similar results were obtained for both rodents and humans. Benzene and its biotransformation products were negative in almost all the Salmonella/microsome assays, with or without metabolic activation [15]. However, it is important to point out that the concentrations of these compounds in the air, the interaction among them and the biological target evaluated are determinant for the manifestation and identification of the toxic effects induced by them. It was [53] assessed the chromosomal aberrations and frequency of 
micronuclei in meristematic and $\mathrm{F}(1)$ root cell after BTEX exposure and found significant increases in frequency of both chromosomal and nuclear aberrations, while the micronucleus frequency was only increased in meristematic cells, showing the difference in cell behavior after BTEX exposure. Others [54] showed that BTEX induced DNA damage in isolated human lymphocytes by single- and double-strand breaks and oxidative base modification and [16] obtained positive results for benzene in both TA98 and TA100 strains without metabolic activation from two representative sites, a roadside and a petrol pump.

Considering the cytotoxicity [31], BTEX cytotoxicity to human lung cells was assessed using three different exposure methods and concluded that if there are any changes in the BTEX exposure matrixes, its mass exposure distribution in cells could differ, changing the toxicity found. Researchers [55] evaluated the cytotoxicity of BTEX metabolites in HeLa cells and found that these compounds affected the levels of the polyamines spermidine, spemine and putrescine, which are known to be important in cell proliferation, causing cytotoxicity. Probably, the low BTEX concentrations found in the workshops were responsible for the absence of toxicity reported in this study. However, at these concentrations, these compounds may cause toxicity by long-term exposure.

It is important to point out that although the areas evaluated presented low BTEX concentrations, which did not present mutagenic and cytotoxic effects, workers are exposed to high levels of these compounds worldwide. In northern China, a study quantified the potential exposure to BTEX emitted by two coke industries. Air from different areas of these industries was analyzed, and all of them presented excessive levels of these pollutants. Workers in these industries were being exposed to these compounds at higher levels than workers from other countries such as the USA [56]. Studies have shown that the air around gas stations frequently contains high BTEX concentrations. In Bangkok, Thailand, a survey with 49 workers at six gas stations found relatively high concentrations of these compounds [22]. A study [28] quantified BTEX compounds inside fitness before and after painting of the spinning room. It showed that the indoor concentrations were higher than the outdoor ones and that, after painting the rooms, these pollutants were found in even higher concentrations, obtaining a $91 \%$ increase for benzene, $907 \%$ for toluene, $182 \%$ for ethyl benzene, $121 \%$ for $\mathrm{m}+\mathrm{p}$-xylenes and $128 \%$ for o-xylene. Hence, it is very important to carry out studies to assess the risk to human health, especially workers, in the face of BTEX exposure.

Overall, higher levels of BTEX concentrations were observed in the painting and varnishing workshops as compared to the external areas, presumably due to the contribution from the products used in both these workshops, such as varnish, alcohol, gasoline, turpentine, solvents, beeswax, carnauba, solvents, PVA paint, synthetic paint, lacquer and spackling. However, the BTEX levels found indoor were below the TWA levels specified by the NIOSH and did not induce mutagenic and cytotoxic activities, possibly due to the low values found and short-term exposure. Despite the low risks found in this study, it is important to point out that the harmful effects of these hydrocarbons on humans are well known, and damage may be even greater after long-term exposure. Thus, more research is needed, with sufficient follow-up to understand the effects of long-term exposure to low levels of BTEX, in order to ensure the safety in the work environment.

\section{CONCLUSIONS}

In all of the workshops evaluated, toluene concentrations were higher. The samples showed a high standard deviation, indicating that different work routines are critical to the evaluation; thus, a high sample number was necessary to obtain a confidence value. I/O ratios indicated that paint and varnish workshops have higher BTEX concentrations. 
The highest concentrations of benzene and toluene were obtained in the paint workshop, and higher concentrations of ethyl benzene, $m+p$-xylenes and o-xylene were obtained in the varnish workshop. The raw materials with the highest BTEX concentrations were those used in the painting and varnish workshops.

The first and second non-carcinogenic risks were obtained for the varnish workshop for $\mathrm{m}+\mathrm{p}$-xylenes. The carcinogenic risk average value and all non-carcinogenic values can be considered indifferent for all workplaces. The maximum carcinogenic risk values can be considered expressive.

Some suggestions to enhance air quality and minimize health effects in the workplaces evaluated are as follows: increase the ambient and local ventilation, substitute solvent-based products with water-based products and establish routines for maintaining the closure of the containers after use.

\section{ACKNOWLEDGMENTS}

The authors wish to thank Research Support Foundation of the State of Rio de Janeiro (FAPERJ) and National Council for Scientific and Technological Development (CNPq) for financial support and research grants.

\section{REFERENCES}

[1] Durmusoglu, E., Taspinar, F. \& Karademir, A., Health risk assessment of BTEX emissions in the landfill environment. Journal of Hazardous Materials, 176, pp. 878-877, 2010.

[2] Guo, H., Murray, F. \& Wilkinson, S., Evaluation of total volatile organic compound emissions from adhesives based on chamber tests. Journal of Air and Waste Management Association. 50, pp. 199-206, 2000.

[3] Jones, A.P., Indoor air quality and health. Atmospheric Environment, 33, pp. 4535-4564, 1999.

[4] Guo, H., Lee, S,C., Chan, L.Y. \& Li, W.M., Risk assessment of exposure to volatile organic compounds in different indoor environments. Environmental Research, 94, pp. 57-66, 2004.

[5] Lim, S.K., Shin, H.S., Yoon, K.S., Kwack, S.J., Um, Y.M., Hyeon, J.H. et al., Risk assessment of volatile organic compounds benzene, toluene, ethyl benzene, and xylene (BTEX) in consumer products. Journal of Toxicology and Environment Health, 77, pp. 1502-1521, 2014.

[6] Ilgen, E., Karfich, N., Levsen, K., Angerer, J., Schneider, P., Heinrich, J., et al., Aromatic hydrocarbons in the atmospheric environment: Part I. Indoor versus outdoor sources, the influence of traffic. Atmospheric Environment, 35, pp. 1235-1252, 2001.

[7] Possanzini, M., Di Palo, V. \& Cecinato, A., Sources and photodecomposition of formaldehyde and acetaldehyde in Rome ambient air. Atmospheric Environment, 36, pp. 3195-3201, 2002.

[8] Wilbur, S., Wohlers, D., Paikoff, S., Keith, L.S. \& Faroon, O., ATSDR evaluation of health effects of benzene and relevance to public health. Toxicology Industrial Health, 24, pp. 263-398. 2008.

[9] Hinwood, A.L., Rodriguez, C., Runnion, T., Farrar, D., Murray, F., Horton, A. \& Galbally, I., Risk factors for increased BTEX exposure in four Australian cities. Chemosphere, 66 , pp. 533-541. 2007.

[10] Barreto, G.E.S., Oliveira, E.S., de Villar F.A.G.A., Santos, G.S., Lima, R.M.F., Costa, S.L., et al., Investigation of toxic factors affecting cells of rat brains exposed to 3-methylcatechol. Brazilian Archives of Biology and Technology, 50, pp. 839-849, 2007. 
[11] Mitsakou, C., Housiadas, K., Eleftheriadis, S., Vratolis, S., Helmis, C. \& Asimakopoulos, D., Lung deposition of fine and ultrafine particles outdoors and indoors during a cooking event and a no activity period. Indoor Air, 17, pp. 143-152, 2007.

[12] Klinmalee, A., Srimongkol, K.. \& Kim Oanh, N.T., Indoor air pollution levels in public buildings in Thailand and exposure assessment. Environmental and Monitoring Assessment, 156, 581-594, 2009.

[13] Farshad, A., Oliaei, H.K., Mirkazemi, R. \& Bakand, S., Risk assessment of benzene, toluene, ethyl benzene and xylenes (BTEX) in paint plants of two automotive industries in Iran by using the COSHH guideline. European Science Journal, 3, pp. 270-276, 2013.

[14] Kumar, A., Singh, B.P., Punia, M., Singh, D., Kumar, K. \& Jain, V.K., Assessment of indoor air concentrations of VOCs and their associated health risks in the library of Jawaharlal Nehru University, New Delhi. Environmental Science and Pollution Research, 21, pp. 2240-2248, 2014.

[15] Whysner, J., Reddy, M.V., Ross, P.M., Mohan, M. \& Lax, E.A., Genotoxicity of benzene ant its metabolites. Mutation Research, 566, pp. 99-130, 2004.

[16] Singla, V., Pachauri, T., Satsangi, A., Maharaj, K. \& Lakhani, A., Comparison of BTX profiles and their mutagenicity assessment at two sites of Agra, India. The Scientific World Journal, Online: https://www.hindawi.com/journals/tswj/2012/272853/, 2012.

[17] Camara-Lemarroy, C.R., Rodríguez-Gutiérrez, R., Monreal-Robles, R. \& GonzálesGonzáles, J.G., Acute toluene intoxication-clinical presentation, management and prognosis: a prospective observational study. BMC Emergency Medicine, 15, pp. 19-25, 2015.

[18] Ministry of Labor and Employment (MTE), Ordinance $n^{\circ} 14$. Change the item of carcinogenic substances of Annex 13, of Regulatory Standard $n^{\circ} 15$ - Unhealthy activities and operations. 1995. http://sislex.previdencia.gov.br/paginas/05/mtb/15.htm. (accessed on: July 2015).

[19] ACGIH, Threshold Limit Value and Biological Exposure. USA, American Conference of Governmental Industrial Hygienists, 2008.

[20] Ministry of Labor and Employment (MTE), Regulatory Standard (NR 9). Prevention program of environmental risks. 1994. http://sislex.previdencia.gov.br/paginas/05/ mtb/9.htm. (accessed on: 28 May 2015).

[21] NIOSH, Manual of Analytical Methods (NMAM), 4th ed., National Institute for Occupational Safety and Health. 2003.

[22] Tunsaringkarn, T., Siriwong, W., Rungsiyothin, A. \& Nopparatbundit, S., Occupational exposure of gasoline station workers to BTEX compound in Bangkok, Thailand. International Journal of Occupational Environment Medicine, 3, pp. 117-125, 2012.

[23] Weisel, C.P., Benzene exposure: an overview of monitoring methods and their findings. Chemical-Biological Interactions, 184, pp. 58-66. 2010.

[24] Rodrigues, F., Milas, I., Martins, E.M., Arbilla, G., Bauerfeldt, G.F. \& Paula, M.D., Experimental and theoretical study of the air quality in a suburban industrial-residential area in Rio de Janeiro, Brazil. Journal of the Brazilian Chemical Society, 18, 342-351. 2007.

[25] Ras, M.R., Marcé, R.M. \& Borrull, F., Volatile organic compounds in air at urban and industrial areas in the Tarragona region by thermal desorption and gas chromatography-mass spectrometry. Environmental Monitoring and Assessment, 161, pp. 389-402, 2010. 
[26] Ward, T.J., Underberg, H., Jones, D., Hamilton, R.F. \& Adams, E., Indoor/ambient residential air toxics results in rural western Montana. Environmental Monitoring and Assessment, 153, pp. 119-126, 2009.

[27] Dewangan, S., Chakrabarty, R., Zielinska, B. \& Pervez, S., Emission of volatile organic compounds from religious and ritual activities in India. Environmental Monitoring and Assessment, 185, pp. 9279-9286, 2013.

[28] Martins, E.M., Quiterio, S.L., Corrêa, S.M., Fortes, J.D.N., Monteiro, M. \& Prestes, B., BTEX inside a spinning classroom. Cadernos de Saúde Coletiva, 22, pp. 218-220, 2014.

[29] de Castro, B.P., Machado, G.S., Bauerfeldt, G.F., Fortes, J.D.N. \& Martins, E.M., Assessment of the BTEX concentrations and reactivity in a confined parking area in Rio de Janeiro, Brazil. Atmospheric Environment, 104, pp. 22-26, 2015.

[30] Corrêa, S.M., Arbilla, G., Marques, M.R.C. \& Oliveira, K.M.P.G., The impact of BTEX emissions from gas station into the atmosphere. Atmospheric Pollution Research, 3 , pp. 163-169, 2012.

[31] Liu, F.F., Peng, C. \& Ng, J.C., BTEX in vitro exposure tool using human lung cells: trips and gains. Chemosphere, 128, pp. 321-326, 2015.

[32] Vilavert, L., Nadal, M., Figueras, M.J. \& Domingo, J.L., Volatile organic compounds and bioaerosols in the vicinity of a municipal waste organic fraction treatment plant. Human health risks. Environmental Science Pollution Research, 19, pp. 96-104, 2012.

[33] U.S.EPA, Risk Assessment guidance for superfund. Volume I - Human health evaluation manual (part A) EPA/540/1-89/002. Washington D.C. 20450, 1989.

[34] R Core Team, 2016. $R$ : A language and environment for statistical computing. R. Foundation for Statistical Computing, Vienna, Austria. https://www.R-project.org/.

[35] Corrêa, S.M. \& Arbilla, G., A two-year of aromatic hydrocarbons monitoring at the downtown area of the city of Rio de Janeiro. Journal of the Brazilian Chemical Society, 18, pp. 539-543, 2007.

[36] Corrêa, S.M., Souza, C.V., Sodré, E.D. \& Teixeira, J.R., Volatile organic compound emissions from a landfill, plume dispersion and the tropospheric ozone modeling. Journal of the Brazilian Chemical Society, 23, pp. 496-504, 2012.

[37] Massolo, L., Rehwagen, M., Porta, A., Ronco, A., Herbarth, O. \& Mueller, A., Indooroutdoor distribution and risk assessment of volatile organic compounds in the atmosphere of industrial and urban areas. Environmental Toxicology, 25, pp. 339-349, 2010.

[38] Yoon, C., Lee, K. \& Park, D., Indoor air quality differences between urban and rural preschools in Korea. Environmental Science and Pollution Research, 18, pp. 333-345. 2011.

[39] Jung, K.H., Artigas, F. \& Shin, J.Y., Personal, indoor, and outdoor exposure to VOCs in the immediate vicinity of a local airport. Environmental Monitoring and Assessment, 173, pp. 555-567, 2010.

[40] Bravo, H., Sosa, R., Sánchez, P., Bueno, E. \& González, R., Concentrations of benzene and toluene in the atmosphere of the southwestern area at the Mexico City Metropolitan Zone. Atmospheric Environment, 36, pp. 3843-3849, 2002.

[41] Chan, C.Y., Chan, L.Y., Wang, X.M., Liu, Y.M., Lee, S.C., Zou, S.C., Sheng, G.Y. \& Fu, J.M., Volatile organic compounds in roadside microenvironments of metropolitan Hong Kong. Atmospheric Environment, 36, pp. 2039-2047, 2002. 
[42] Dutta, C., Som, D., Chatterjee, A., Mukherjee, A.K., Jana, T.K. \& Sen, S., Mixing ratios of carbonyls and BTEX in ambient air of Kolkata, India and their associated health risk. Environmental Monitoring and Assessment, 148, pp. 97-107, 2009.

[43] Palmiotto, M., Fattore, E., Paiano, V., Celeste, G., Colombo, A. \& Davoli, E., Influence of a municipal solid waste landfill in the surrounding environment: toxicological risk and odor nuisance effects. Environmental International, 68, pp. 16-24, 2014.

[44] LaGrega, M.D., Buckingham, P.L. \& Evans, J.C., Hazardous Waste Management, McGraw Hill: New York. ISBN 0-07-019552-8, 1994.

[45] Rodrics, J.V., Brett, S.M. \& Wrenn, G.C., Significant risk decisions in Federal regulatory agencies. Regulatory Toxicology and Pharmacology, 7, pp. 307-320, 1987.

[47] Sarigiannis, D.A. \& Gotti, A., Biology-based dose-response models for health risk assessment of chemical mixtures. Fresenius Environmental Bulletin 17, pp. 1439-1451, 2008.

[48] Sarigiannis, D., Gotti, A., Cimino Reale, G. \& Marafante, E., Reflections on new directions for risk assessment of environmental chemical mixtures. International Journal of Risk Assessment and Management, 13, pp. 216-241, 2009.

[49] Gilman, J.B. Lerner, B.M., Kuster, W.C. \& de Gouw, J.A., Source signature of volatile organic compounds from oil and natural gas operations in northeastern Colorado. Environmental Science \& Technology, 47, pp. 1297-1305, 2013.

[50] Mortelmans, K. \& Zeiger, E., The Ames Salmonella/microsome mutagenicity assay. Mutation Research, 455, pp. 29-60, 2000.

[51] Mazzeo, D.E., Matsumoto, S.T., Levy, C.E., de Angelis, D.F. \& Marin-Morales, M.A., Application of micronucleus test and comet assay to evaluate BTEX biodegradation. Chemosphere, 90, pp. 1010-1036, 2013.

[52] Benzene, IARC Monographs on the Evaluation of the Carcinogenic Risk of Chemical to Human. Online: http://monographs.iarc.fr/ENG/Monographs/vol100F/mono100F24.pdf, 2002. (accessed on: 10 Sept 2018).

[53] Mazzeo, D.E., Fernandes, T.C. \& Marin-Morales, M.A., Cellular damages in the Allium cepa test system, caused by BTEX mixture prior and after biodegradation process. Chemosphere, 85, pp. 3-18, 2011.

[54] Chen, C.S., Hseu, Y.C., Liang, S.H., Kuo, J.Y. \& Chen, S.C., Assessment of genotoxicity of methyl-tert-butyl ether, benzene, toluene, ethyl benzene, and xylene to human lymphocytes using comet assay. Journal of Hazardous Materials, 153, pp. 351-356, 2008.

[55] Shen, Y., In vitro cytotoxicity of BTEX metabolites in HeLa cells. Archive of Environmental Contamination and Toxicology, 34, pp. 229-234, 1998.

[56] He, Q., Yan, Y., Zhang, Y., Wang, X. \& Wang, Y., Coke worker's exposure to volatile organic compounds in northern China: a case study in Shanxi Province. Environmental Monitoring and Assessment, 187, pp. 1-11, 2015. 